\title{
Human Rights of Forced Migrants During the COVID-19 Pandemic: An Opportunity for Mobilization and Solidarity
}

\author{
Kathryn Libal ${ }^{1}\left[\right.$. Scott Harding ${ }^{2} \cdot$ Marciana Popescu $^{3} \cdot$ S. Megan Berthold ${ }^{2} \cdot$ Grace Felten $^{2}$
}

Accepted: 13 January 2021 / Published online: 19 March 2021

(c) The Author(s), under exclusive licence to Springer Nature Switzerland AG part of Springer Nature 2021

\begin{abstract}
The question of human mobility is inextricably tied to the COVID-19 pandemic that started in late 2019 and whose effects continue to unfold. Human mobility-especially with global advances in transportation and interconnectedness-is an important factor in the spread of the pandemic. Yet, the impact of the COVID-19 pandemic on the millions of people forced to migrate for safety and economic reasons has received little attention. In this article, we provide an overview of human rights challenges that forced migrants currently face during this pandemic. While we do not address all dimensions of the impact COVID-19, we highlight several troubling situations that have emerged for refugees and asylum seekers. These include entry restrictions into some countries that had formerly welcomed asylum seekers, overt and covert forms of exclusion of migrants from labor markets due to rising unemployment and economic hardship, and implementing new deportation policies, as well as new exclusionary policies for immigrants who would have been authorized to work in past. Without concerted efforts to amplify solidarity with all forced migrants and ensure their human rights, discriminatory and restrictionist policies enacted in the Global North over the past decade will become entrenched. As a result, fewer refugees and asylum seekers will be accorded protection and continue to face violence and persecution in their home countries.
\end{abstract}

Keywords Refugees · Asylum seekers · COVID-19 $\cdot$ Detention $\cdot$ Health

\section{Introduction}

The question of human mobility is inextricably tied to the COVID-19 pandemic that started in late 2019 and whose effects continue to unfold. Human mobility-especially with global advances in transportation and interconnectednessis an important factor in the spread of the pandemic. Yet, the impact of the COVID-19 pandemic on the millions of people forced to migrate for safety and economic reasons has received too little attention. This has been exacerbated for those living in detention facilities or refugee camps with limited ability to control their surroundings and few material resources to mitigate against the SARS-CoV-2

Kathryn Libal

kathryn.libal@uconn.edu

1 School of Social Work and Human Rights Institute, University of Connecticut, Connecticut, Hartford, USA

2 School of Social Work, University of Connecticut, Connecticut, Hartford, USA

3 Graduate School of Service, Fordham University, New York, USA virus's spread or address its health and economic effects. As national borders have closed, movement itself has become a casualty of the virus. ${ }^{1}$ Thus, for those fleeing persecution, being able to make such asylum claims, let alone fly or cross over land or sea, has become increasingly challenging (Slack \& Heyman, 2020). Within weeks of the World Health Organization's (WHO) identification of the novel coronavirus as a pandemic, many countries moved to restrict travel and/ or close borders entirely. Even as a gradual easing of travel restrictions in some countries occurred in mid-2020, being able to resettle as a refugee through the United Nations (UN) resettlement process or to claim asylum remains problematic (Ramji-Nogales \& Goldner Lang, 2020).

Shortly after the WHO pressed governments to take measures to limit the coronavirus's spread, human rights advocates and UN humanitarian bodies raised warnings about how SARS-CoV-2 virus containment policies could

\footnotetext{
${ }^{1}$ According to World Health Organization (WHO) guidelines, we use "SARS-CoV-2" (severe acute respiratory syndrome coronavirus 2) to refer to the virus itself (World Health Organization, n.d.). We use "COVID-19" to refer to the disease that can be caused by the virus, which is short for Coronavirus Disease 2019, the year of discovery. We also use the term "COVID-19" to refer to the current pandemic.
} 
have unintended consequences for those seeking asylum or third country resettlement as refugees. They noted that asylum seekers in detention or refugees in camps were also at grave risk of contracting COVID-19 due to cramped and unsanitary living quarters. Orcutt et al. (2020) recently summarized what was at stake: "Principles of solidarity, human rights, and equity must be central to the COVID19 response; otherwise the world risks leaving behind those who are most marginalized" (p. 1482). In this article, we provide an overview of human rights challenges that forced migrants currently face. While we do not address all dimensions of the impact of the coronavirus, we highlight several troubling situations that have emerged for refugees and asylum seekers. These include entry restrictions into some countries that had formerly welcomed asylum seekers, overt and covert forms of exclusion of migrants from labor markets due to rising unemployment and economic hardship, implementing new or enhanced deportation policies, as well as introducing new exclusionary policies for immigrants who would have been authorized to work in past.

By March 2020, scholars and activists had identified the threat of extreme restrictionism or containment facing asylum seekers and refugees. More than 600 academics, lawyers, and human rights advocates signed a document, "Human mobility and human rights in the COVID-19 pandemic: Principles for protection for migrants, refugees and other displaced persons," developed by Columbia University's Mailman School of Public Health, Cornell Law School, and The New School's Zolberg Institute on Migration and Mobility (2020). The declaration outlined 14 principles grounded in international human rights law that must be upheld during the pandemic (hereafter called the 14 Principles of Protection). These concerns underscore why the human rights of asylum seekers, refugees, and other forced migrants must be prioritized during the COVID-19 pandemic.

Among the principles, the declaration calls for states to respect the right to health of migrants, refugees and others who are displaced, including that "the provision of essential medicines, prevention, and treatment are provided" without discrimination (Columbia University, et al., 2020). States should also refrain from and prevent non-state actors from actions that "stigmatize or incite violence against persons on account of their actual or perceived health status, in particular when such stigmatization is linked to nationality or immigration status." The document further notes that all restrictions on mobility must respect the rights of persons to "leave any State or to renter their home States," and states must "respect the liberty of movement of all persons within their territory." Especially important in the context of asylum seekers, it asserts, states much respect the principle of "non-refoulement, including non-return to a real risk of persecution, arbitrary deprivation of life, torture, or other cruel, inhuman, or degrading treatment." These concerns align with a recent call for the UN Human Rights Committee, which monitors the International Covenant on Civil and Political Rights (ICCPR) (United Nations, 1966a), to develop a general comment on state's responsibilities for upholding civil and political rights in the context of public health emergencies. Sun (2020) suggests that an "authoritative body" such as the Human Rights Committee must address "the necessity and proportionality of state responses and the misuse of emergency powers during the pandemic" (p. 387).

The declaration also identifies principles related to healthcare grounded in human rights standards. States must refrain from enforcing immigration law in a way that "increases the risk of transmission" and such enforcement must adhere to due process rights; immigration detention is "impermissible where such detention would expose them to serious risks to their health and life due to the COVID-19 pandemic." States must also "take effective measures to mitigate COVID-19 transmission" for those living in "camps, collective shelters, and settlements." Access to health information for migrants, refugees, and asylum seekers is critical. States must ensure that migrants, refugees, and other displaced persons "have a right to information about COVID-19, including information related to symptoms, prevention, control of spread, treatment, and social relief," including access to the internet as an "indispensable source of information." In addition, states must "ensure the protection of the rights of displaced women, girls and gendernon-conforming people" and other groups that may be particularly vulnerable including "older people, persons with disabilities, and children."

These are comprehensive principles that were not widely upheld prior to the pandemic, but in the current context they have taken on added urgency. Without concerted efforts to amplify solidarity with all forced migrants and ensure their human rights, discriminatory and restrictionist policies enacted in the Global North over the past decade will become entrenched (Libal \& Kashwan, 2020). As a result, fewer refugees and asylum seekers will be accorded protection and continue to face violence and persecution in their home countries. In the following, we address human rights deficits and potential for rights realization for these groups, seeking to illustrate from our research in Europe and the USA (Berthold \& Libal, 2019; Popescu \& Libal, 2018), how human rights matter for refugees and asylum seekers during the pandemic and beyond.

\section{COVID-19 and Refugee Camps}

Currently, refugees seeking safety from violence and disaster face a new set of safety concerns related to the coronavirus pandemic (Cordaid, 2020; Alemi et al., 2020). 
According to UN estimates, 2.6 million refugees live in camps globally (United Nations High Commissioner for Refugees [UNHCR], n.d.). The WHO's guidelines for protection from COVID-19 include washing hands with soap and water, avoiding crowds, wearing masks in public, and social isolation when ill (WHO, 2020). These guidelines are challenging and, at times, impossible in refugee camps, which are meant to be temporary shelters where those fleeing conflict, natural disasters, and human rights violations can find safety. Camps ideally provide basic necessities, such as housing, food, and healthcare. However, most camps are designed to house many people close together, and past disease outbreaks of cholera and Ebola show that this close proximity can cause diseases to spread rapidly (Cordaid, 2020).

In addition to crowded spaces, refugee camps often fail to provide access to adequate amounts of water and sanitation to allow for proper hygiene, further increasing the spread of disease. The International Rescue Committee (IRC, 2020) recently compared the population density of camps in Bangladesh, Greece, and Syria to that of the Diamond Princess cruise ship. The IRC concluded that the disease was likely to spread even more quickly in these camps due to the combination of high population density and lack of access to water and sanitation. Since these conditions are present in most refugee camps throughout the world, refugees and humanitarian workers will likely face basic health challenges. Other concerns for displaced individuals include COVID-19-related travel restrictions that may force some, out of desperation, to attempt more dangerous border crossings (UN High Commissioner for Refugees [UNHCR], 2020a) Refugee camps in specific areas in the world have additional dangers. The UN High Commissioner for Refugees (UNCHR) is concerned about conflicts in some regions in West and Central Africa, where over nine million forcibly displaced individuals reside, exacerbating challenges faced by an already vulnerable population in the midst of the pandemic (UNHCR, 2020d).

Additionally, the impact of COVID-19 may overwhelm fragile healthcare infrastructures and struggling economies in developing countries where 85 percent of refugees are housed (UNHCR, 2017). Many of those living in refugee and internally displaced persons camps rely on the informal economy, which is disproportionately impacted during public health crises (Girls Not Brides, 2020; Balcioglu \& Erdogan, 2020). Also, those living in refugee camps often do not have access to national healthcare systems.

Displaced women and girls face additional risks during the pandemic. The restrictions on movement and reduced interaction with community members during social distancing amplifies the effects of intimate partner violence (UNHCR, 2020b). The negative impact on the economy may force some women to participate in survival sex to meet financial obligations, and more young girls may be forced to marry early. During the Ebola outbreak in West Africa in 2014-2016, school closings led to an increased rate of girls' school dropout, sexual abuse, early marriages, and early pregnancies (Girls Not Brides, 2020). Humanitarian staff and governments hosting refugees should consider these gendered circumstances.

\section{Greece: COVID-19 Effects on Refugees and Migrants in Camps}

Prior to the pandemic, Greece struggled to host approximately 115,000 asylum seekers (UNHCR, 2020c). The country is still recovering from the 2008 financial collapse, has high taxes, and severe austerity measures remain in place (Karagkounis, 2017). Since the 2016 EU-Turkey agreement, those seeking asylum in EU countries are required to remain within Greece during their application process which can take several years. Approximately 40,000 refugees reside on five Greek islands, with about 35,000 living in the Reception and Identification Centers (RICs) that only have the capacity to hold 5400 individuals in total (UNHCR, 2020c). Thousands live in informal structures outside of camps because of lack of capacity; some camps are ten times overcapacity. This overcrowding is "causing major protection, security and now health risks, especially for the most vulnerable individuals in the context of COVID-19" (UNHCR, 2020c). In November 2019, Greece announced it would transfer an estimated 20,000 people from island camps onto the mainland due to overcrowding, but has not done so (Human Rights Watch [HRW], 2020b).

The lack of space in the RICs is a major obstacle for social distancing. Waiting in line is a daily reality for most camp residents. A Syrian refugee living in a camp on the island of Samos told Human Rights Watch (HRW), "I spend around 3 hours in line every day to get food. If we are 200 people waiting for food, the camp is not even big enough for all of us to be able to wait and keep that (recommended) distance between each other" (2020b). Some refugees have been showering only once a week to avoid lines. Others report waiting all day in line to visit a health clinic. Water and sanitation shortages have also been reported. Moria, what was the largest refugee camp in Europe located on the Greek island of Lesvos prior to two devastating fires in September, 2020, had a capacity for 2200 individuals. Until it was disbanded after the fire, it housed 18,000 refugees (Mpoke Bigg, 2020). In some parts of the camp, 1300 people shared one water tap (International Rescue Committee, 2020); 210 people shared a toilet and 630 shared a shower (Fallon, 2020). The fires destroyed the Moria camp and initially left thousands without shelter. While the subsequent removal of several thousand people to the Greek mainland eased overcrowding, by December more than 7000 refugees were 
still living at a hastily constructed site called Mavorovouni camp. Built on a former military firing range, concerns over potential lead contamination and the presence of unexploded munitions at the camp have recently been raised (European Council on Refugees and Exiles, 2020).

COVID-19 has exacerbated already sub-standard conditions for pregnant women in some island camps. Pregnant women shared stories of "sleeping in overcrowded tents on the ground lined only with thin mats or blankets, struggling to reach toilets over rough terrain, and being returned to these conditions within days of caesarean births" (Margolis, 2020). Disruption of maternal health services because of COVID-19 could make matters worse with increased maternal mortality rates, as shown in past instances of disease outbreaks. In response, the European Court of Human Rights ordered the Greek government to improve the conditions in the Pyli camp for one pregnant woman.

Asylum seekers are at the mercy of the geopolitical realities of their host country and surrounding countries. Shortly before the pandemic, Turkish President Recep Tayıp Erdoğan made the decision to stop intercepting asylum seekers migrating through Turkey to Greece (Boffey, 2020). The Greek government responded to this by suspending asylum applications, violating international law, the Convention on Refugees, and the EU's founding charter (Fouskas et al., 2020). The suspension, beginning in early March 2020, was intended to be in place for 30 days but was extended over 6 weeks due to COVID-19 concerns. During this time, almost 2000 newly arrived asylum seekers were held in two detention centers in substandard conditions, with no precautions being taken for COVID-19 besides having their temperatures taken on arrival (HRW, 2020c).

As COVID-19 cases began to appear in Greece in mid-March, the government restricted the movement of residents within island camps (HRW, 2020b). Officials prohibited leaving camps except for buying necessities; informal schools closed; and camps were closed to nonessential visitors (HRW, 2020b). The situation heightened anxiety in an already tense environment. Also, increased fighting among refugees was reported within what was then Europe's largest refugee camp near Moria on Lesbos Island (Carassava, 2020). One refugee shared his concern about the camp: "There is only one supermarket inside the camp and it's overcrowded and not enough for people. It also makes people's anxiety worse to be all the time inside the camp and not able to leave" (Fallon, 2020).

Restrictions on movement for Greek citizens were lifted in early May 2020, but they have been extended for camp residents several times, with the latest extension to early July 2020 (Carassava, 2020); these were justified as a public health concern to "limit the spread of COVID-19 in areas of overcrowding" (Cosse, 2020). Human rights organizations have criticized the Greek government for not responding effectively to protect the rights of refugees during the pandemic, yet Greek officials claim they need more assistance from the European Union and humanitarian community to address COVID-19 risks in camps.

\section{Refugee Resettlement}

\section{Global Refugee Resettlement Program and Risks of Long-term Suspension}

Resettlement of refugees from a country of asylum to one that offers permanent residence and a path to citizenship is one of the UNHCR's "three durable solutions" (UNHCR, 2003). However, this is the least common outcome due largely to the unwillingness of potential host countries to offer a substantial number of permanent resettlement spaces. Thus, at the end of 2018 there were more than 20 million refugees "of concern" to UNCHR, and yet in 2019 only 81,600 were recommended for permanent resettlement worldwide (UNCHR USA, n.d.). On average, each year, fewer than $1 \%$ of all refugees are able to gain permanent resettlement to third countries such as the USA, Canada, Australia, and European states.

Historically, the USA has accepted the largest number of refugees through the global refugee resettlement program. In 2018, however, it lost that distinction due to the Trump administration's radical cuts to US refugee admissions (Cecco, 2019). This was compounded in March 2020, when, citing the spread of COVID-19, UNCHR temporarily suspended all refugee resettlement. These changes, however "temporary," are a cruel irony: refugees living in camps are particularly at risk of contracting COVID-19 and can access few resources to combat the disease, as noted earlier. Claiming that the coronavirus posed a public health threat, in March 2020, the Trump administration also implemented several policy changes to how the USA handles the cases of refugees and asylum seekers. These included suspending the family reunification program; failing to offer refuge to unaccompanied minors; and no longer prioritizing resettlement of the most vulnerable refugees in camp and urban situations abroad (Somin, 2020). For those fleeing conflict or persecution, even individuals and families identified by UNHCR for third country resettlement, the promise of sanctuary in the USA or other countries has become illusory amidst the COVID-19 pandemic. As president, Joe Biden has pledged to increase annual refugee admissions to as much as 125,000 people a year, and to "raise it over time commensurate" with US "responsibility ... values, and the unprecedented global need" (Biden Harris, n.d.). Despite this commitment, the pandemic will 
present unique challenges for refugee resettlement to the USA. Hauslohner (2020) suggests that the "ongoing surge of coronavirus cases in the United States and globally, and the associated economic slump-including the high domestic unemployment rate-are also likely to hinder the refugee resettlement process."

The consequences of COVID-19 have also been profound for refugees already resettled in the United States, where the rapid spread of the disease has destabilized the economy and revealed weakness in the health infrastructure. Refugees are more likely to work in low-wage, low-skilled jobs (often deemed "essential services") and thus are at higher risk for contracting COVID-19 (Centers for Disease Control and Prevention [CDC], n.d.), while many lack adequate health coverage. Closer examination of the US case provides insights into the unique vulnerabilities and risks faced by newly resettled refugees, as well as the simultaneous efforts of resettlement organizations and volunteers to help mitigate those hazards.

\section{Resettled Refugees as “Essential" and Vulnerable in the USA}

It is widely recognized that newly arrived refugees face obstacles in terms of securing health, housing, and economic security. These conditions have been exacerbated during COVID-19. As the Centers for Disease Control and Prevention (CDC) recently noted:

Due to social and economic conditions, resettled refugees face many of the same challenges that lead to poorer health for some racial and ethnic minority groups in the United States. Refugees also face the challenges of a new healthcare system and finding health information they can understand (CDC, n.d.).

The CDC also found that refugees are clustered in jobsmeatpacking, grocery stores, janitorial, restaurants-where they are often required to continue work despite coronavirus outbreaks in the workplace or their communities. The CDC has encouraged health and public health professionals, and community organizations and refugee resettlement agencies to provide refugees with "culturally sensitive resources on COVID-19 prevention, symptoms, and self-management" (CDC, n.d.). They also recommend giving refugees personal protective equipment and cleaning supplies, which may be lacking or inadequate in their home or workplace. Despite these recommended steps, it is unclear if most refugees have adequate information and supplies to protect against infection by the SARS-CoV-2 virus.

Amidst record high unemployment, some resettled refugees have lost jobs and faced challenges accessing unemployment benefits, compounding unstable housing and food shortages. Based on information from US resettlement agencies, many refugees and asylum seekers have grappled with food insecurity; some organizations have set up emergency funds to prevent eviction and developed food banks and food delivery services to help address unmet needs among refugees. The lack of paid sick leave is a particular challenge that most service sector, agricultural, or other low-wage workers face, and is relevant to the experience of refugees in the USA. Clarke et al. (2020) find that recently resettled refugees are at elevated risk for contracting COVID-19, such as "being more likely to experience poverty and live in crowded housing, being employed in less protected, service-sector jobs, experiencing language and health care access barriers, and have higher rates of co-morbidities" (pp. 1-2).

\section{Responding to Refugee Needs}

Voluntary agencies, such as Hebrew Immigrant Aid Society (HIAS) and the International Rescue Committee, and hundreds of local refugee-serving organizations across the country, recognized after social distancing measures were enacted that their work would face new challenges. Thus, refugee resettlement organizations are providing "essential services" during COVID-19, continuing to facilitate remote "triage" for healthcare access, supplying needed information about prevention of the spread of disease, and offering emergency income support and access to food banks. In one example, Unite Oregon created the "Coronavirus Immigrant and Refugee Support Fund," to assist workers laid off from service sector jobs, such as in restaurant and hotel industries. In asking for support for all "vulnerable community members in need," the organization noted: "We know many of our allies are receiving their federal stimulus payments-will you contribute all or part of that to ensure that immigrant families (including refugees) are able to put food on their table and keep their housing?" (Unite Oregon, n.d.).

In addition to financial donations, critical during a time in which the federal government has cut funding to resettlement agencies (Roldan, n.d.), community members have also mobilized in response to COVID-19 to help provide key services. Several of the authors' interviews with grassroots activists show that community interest to support refugees spiked in the weeks after implementation of stay at home restrictions and has remained high (Harding \& Libal, 2020). Such efforts have helped ensure that refugees basic rights to housing, food, and health are met in a context of limited government support.

Whether creating mutual aid groups or launching innovative (information) campaigns, local communities have been essential to providing support during this crisis. Volunteers have served refugees and asylum seekers at new or expanded food banks at resettlement organizations; community centers; and/or at churches, synagogues, or mosques. Most have taken their work "online" as well, providing remote tutoring for English as a Second 
Language courses, citizenship test preparation, job-training programs, or other forms of online community building. As the pandemic spiked in late 2020, however, the economic impacts on resettled refugees and other immigrants intensified. For example, immigrant women now experience the highest levels of unemployment in the United States (Gelatt et al., 2020). Efforts to support refugees and other immigrants through mutual aid are unlikely to meet the extent of need amidst continued economic crisis.

Beyond direct services, it is important to emphasize the heightened role of political advocacy for refugees. A number of voluntary agencies and local resettlement organizations have pressed federal and state governments for emergency financial support to refugees and asylum seekers. They also have requested that US Citizenship and Immigration Services restore full funding to the resettlement program, regardless of whether new refugees arrive in the future. In fact, many organizations and voluntary agencies have begun to advocate for an end to restrictive immigration measures implemented by the Trump administration. However, as immigrant rights groups have emphasized, it will take some time to rebuild the immigration justice system and enhance human rights protections (Preston, 2020).

\section{The Rights and Well-Being of Detainees}

Protecting the health and well-being of migrants and asylum seekers held in detention from COVID-19 is not just a matter of public health and public policy; it is a matter of human rights (Berwick et al., 2020; Amon, 2020). Health is a human right affirmed by numerous international human rights instruments and has implications for migrants in detention. The International Covenant on Economic, Social, and Cultural Rights (ICESCR) (United Nations, 1966b), for example, requires states to implement needed measures for "the prevention, treatment and control of epidemic, endemic, occupational, and other diseases" (Article 12.1). Notably, while the United States has not ratified the ICESCR nor the Convention on the Rights of the Child (UN CRC, 1989), it is arguably responsible for upholding these standards due to its other human rights obligations and domestic law. International law has established "parameters... to which States must adhere in their responses to the COVID-19 crisis, including to protect all those deprived of liberty" (United Nations Network on Migration, n.d.). The US Supreme Court has also ruled that carceral conditions that pose an unreasonable risk of harm, such as developing a communicable disease, violate the prohibition against cruel and unusual punishment in the Eighth Amendment (Helling v. McKinney, 1993).

Immigration detention facilities operated by the Department of Homeland Security (DHS), or jails and private prisons under contract with DHS, are congregate environments with conditions that endanger the health and lives of detainees during this pandemic (CDC, 2020a). Detainees are typically housed in overcrowded and unsanitary conditions, with inadequate ventilation and limited access to fresh air, and are at risk of getting the virus from staff, visitors, and new detainees. Many detention facilities are not employing quarantining practices, according to Amnesty International (2020b). A wife of one detainee in the Colorado-based Aurora Detention Facility asserted, “Three guys have gotten fevers and haven't been moved out of the general population. These guys are sitting ducks for contracting COVID-19. My husband especially needs out right now. He'll die of illness!" (Amnesty International, 2020b, p. 9). Many prisons continue to prohibit the use of hand sanitizers as contraband (Tolan, 2020). Such conditions violate public health guidelines in the face of the coronavirus pandemic for social distancing and washing and sanitizing one's hands and environment (CDC, 2020c). Further, detainees often lack adequate access to preventive and basic healthcare (CDC, 2020a) which can exacerbate the impact of COVID-19 on physical and mental health.

Nearly half of US detainees tested for COVID-19 have the SARS-CoV-2 virus (Berwick et al., 2020). With lack of complete testing and asymptomatic infection, it is likely that there are more undetected cases. It is impossible to adhere to social distancing and other public health guidelines while detained. A widely endorsed recommendation by public health and human rights organizations, as a result, is to immediately release those who are detained, prioritizing vulnerable sub-populations such as children, the elderly, and those with medical conditions that put them at increased risk of contracting or developing complications from COVID-19 (Berwick et al., 2020; Inter-Agency Standing Committee, 2020). Protests by detainees, advocates, and healthcare providers, as well as other efforts by civil society, have called for releasing those in detention amid the pandemic in the USA, Mexico, and other countries (Coronado, 2020; Da Silva, 2020; Gonzalez, 2020; Human Rights Watch, 2020d; Médecins Sans Frontières [MSF], 2020).

Despite these requests, the USA has not moved to release all migrants held in detention. At the end of March 2020, US District Judge James E. Boasberg urged the US Immigration and Customs Enforcement (ICE) to release detained migrant families in the wake of the coronavirus as part of a lawsuit involving approximately 1350 migrant family members housed in two centers in Texas and one in Pennsylvania (Hsu, 2020b). Some families were released, while others languished in dangerous settings (Hsu, 2020a). By late May 2020, some 350 family members remained in detention and parents faced tough decisions. For example, ICE reportedly asked parents to decide whether to let their children, some as young as one-year-old, to be released by themselves or 
remain in detention together (Echavarri \& Lanard, 2020; Merchant, 2020). Notably, federal judge Dolly M. Gee of the US District Court for the Central District of California ruled in late June 2020 that children held in one of three family detention centers (in Pennsylvania and Texas) must be released by July 17, 2020, if they can be released into custody of a guardian or family member (Jordan, 2020). Legal battles over this ruling and the Flores Settlement continued throughout 2020. Whether Judge Gee's ruling will be implemented for these children under the Biden administration, or if it will affect policies related to COVID19 and unaccompanied children in other settings, remains to be seen.

More comprehensive measures, however, are needed. While the CDC (2020c) has issued guidance for operational preparedness, prevention, and management of COVID-19 for those in detention, human rights advocates call for more comprehensive action (Amon, 2020; UN Office of the High Commissioner for Human Rights, 2020). This includes releasing asylum seekers, those detained pre-trial, migrant children, and others particularly vulnerable to COVID-19 (or putting them in alternative facilities that can ensure appropriate care and protection), and ending mandatory immigration detention and establishing alternatives (Amon, 2020; Berwick et al., 2020; Inter-Agency Standing Committee, 2020; United Nations Network on Migration, n.d.).

As of late May 2020, two detainees were known to have died from the coronavirus while others with identified medical conditions were still being detained by ICE (Montoya-Galvez, 2020). More than 4600 asylum-seekers who had established a credible fear of being tortured or otherwise persecuted in their native countries remained in detention in unsafe conditions (Montoya-Galvez, 2020). The Trump Administration halted asylum processing on its Southern border, put most immigration proceedings on hold, and deported a number of migrants who tested positive for COVID-19 (Narea, 2020). By August, 2020 Amnesty International reported that 21,066 individuals were in immigration detention in the USA, including approximately 100 families, in conditions that a federal judge characterized as "on fire" (Amnesty International, 2020a) with high rates of confirmed COVID19 cases. The situation for those in ICE custody worsened in the following months as numbers as the COVID virus spread throughout the USA. In August, ICE also reported six detainee deaths from COVID-19 (Erfani et al., 2020), while data from its website showed that the spread of the virus was more rapid in ICE detention centers when compared to the US population (with 13 times the case rate on average).

While this discussion has focused on the USA, similar conditions exist in other countries where asylum seekers and migrants are detained, such as Mexico, France, Greece, and Italy (Médecins Sans Frontières [MSF], 2020). In response, several countries have taken action to mitigate the impact of COVID-19 by prioritizing alternatives to the detention of migrants. For example, Spain released many detained immigrants while pledging to discharge all detained migrants (United Nations Network on Migration, n.d.). A federal judge in Mexico ordered that the government transfer all separated and unaccompanied children who were detained to community shelters and release detained migrants deemed most vulnerable to contracting SARS-CoV-2 (United Nations Network on Migration, n.d.). Mexico later announced it had emptied its detention centers. Yet, as a representative from the Jesuit Refugee Service in Mexico noted: "We fought for people to be let out of the detention centers, because we thought that the risks were greater inside, but there have to be alternatives, so they do not end up homeless... In the markets and streets, we see a degree of misery far higher than before" (Averbuch, 2020). The United States should take similar steps to release detained migrants, but must also ensure that they have safe alternatives that do not leave them destitute and at risk. Doing so would be wise in terms of public health, and also promote the human rights of detained migrants.

\section{Unaccompanied Child Migrants}

\section{The Global Context for Unaccompanied Children During COVID-19}

Unaccompanied child migrants are a particularly vulnerable group affected by the COVID-19 pandemic. According to UNHCR (2020a), 12.7 million refugees and 1.1 million asylum seekers globally are children. Unaccompanied child migrants "are children who have been separated from both parents and other relatives and are not being cared for by an adult who, by law or custom, is responsible for doing so" (UNHCR, 1997). ${ }^{2}$ Unaccompanied children depend on a complex, inadequate, and increasingly restrictive set of international protections and legal provisions pertaining to the rights of the migrants and refugees and children's human rights instruments (Papoutsi, 2020).

Core human rights principles with respect to all children have been established by the Convention on the Rights of the Child (CRC) (UN, 1989). Any decisions, legislative measures, or emergency policy provisions should be (1) nondiscriminatory; (2) centered on the best interests of the child without discrimination; 3) safeguard the right to life, survival and development of all children; and (4) engage

\footnotetext{
${ }^{2}$ In U.S. literature the group is often referred to as unaccompanied minors. We have chosen to use the international term and not to use the acronym UAC for "unaccompanied child" because it distances the reader from the fact that we are talking about children.
} 
children, and respect their views and voices, throughout any decision-making processes pertaining their rights (Papoutsi, 2020). In addition, the UN Committee on the Protection of the Rights of All Migrant Workers and Members of Their Families (CMW) and the UN Committee on the Rights of the Child (CRC) have established a protection framework to address the needs of child migrants, elaborated in joint general comments on the rights of child migrants (UN CMW/CRC, 2017a, b). These human rights norms are applicable to the rights of children globally, and within the USA, regardless of whether or not a given country has ratified the treaties.

During the COVID-19 pandemic many containment and mitigation measures taken by states have had a negative impact on unaccompanied children and thus violate these key principles (Human Rights Watch, 2020a). Border closings adopted by 167 countries, including 57 states that make no exceptions for asylum seekers (UNHCR, 2020b), have drastically reduced any existing protections provided to unaccompanied children. This, in turn, has increased the risks for violence and child trafficking (UN News, 2020a). Human Rights Watch (2020e) reports that a high number of children are detained globally whose asylum cases have been postponed indefinitely due to the pandemic. School closures further disrupt these children's education. Moreover, the transition to remote learning, due to connectivity issues, lack of equipment, language barriers, and other factors, impedes access and use of technology. According to UNHCR, school closures also increase food and water insecurity for many of these children (UNHCR, 2020a). As a result, UNICEF warns that the pandemic is rapidly becoming a "child rights crisis" (UN News, 2020b).

\section{A Human Rights Disaster for Unaccompanied Children in the USA}

The US COVID-19 mitigation measures violate all core principles of the CRC, principles of the International Covenant on Civil and Political Rights (ICCPR) (United Nations, 1966a), Convention Against Torture (CAT) (United Nations, 1984), and domestic law such as the Trafficking Victims Protection Reauthorization Act of 2018 (Refugees International, 2020). While the United States has not ratified the main CRC treaty, it has ratified the Optional Protocol on the Sale of Children, Child Prostitution and Child Pornography, which entails protection of unaccompanied children from trafficking and exploitation during migration (United Nations, 2002). When unaccompanied children arrive at the US-Mexico border, they face multiple human rights violations. Often, they are prevented from claiming

\footnotetext{
3 The order was extended indefinitely on May 21, 2020 (CDC, 2020b).
}

asylum, deported without due process, or placed within the child welfare system.

In March 2020, the CDC issued an emergency order with a major impact on forced migrants in general and on unaccompanied children in particular. ${ }^{3}$ The order, enacted under Title 42 of the Public Health Safety Act, allows immigration officials to expel undocumented migrants at the southern border, including unaccompanied children, and suspend asylum legal procedures until further notice during the COVID-19 pandemic (CDC, 2020b). Since then, approximately 13,000 unaccompanied minors have been deported from the USA, without any screening for credible fear of persecution in their home country or potential human trafficking (American Civil Liberties Union, 2020; US Committee on Refugees and Immigrants, 2020). This order violates US obligations under the 1951 Refugee Convention (Nicolosi, 2020; Hathaway, 2005), the ICCPR (EstradaTank, 2016), and US immigration laws (Human Rights Watch, 1998). Moreover, these practices ignore provisions under the Optional Protocol to the Convention on the Rights of the Child on the sale of children, child prostitution, and child pornography (United Nations, 2002) and the Victims of Trafficking and Violence Protection Act of 2000 (Villagran, 2020).

For the estimated 1800 unaccompanied children in detention centers in the US (O'Toole \& Carcamo, 2020) basic protections against the pandemic can exacerbate existing risks for major physical and mental health challenges, including death (Cheatham, 2020). While immigration advocates recently pressured state governments to release unaccompanied children to sponsors, the Trump administration refused and instead expedited deportations (Garcia Bochenek, 2020).

The impacts of such blatant violations of fundamental human rights for unaccompanied children are complex and yet to be fully understood. Current measures established to mitigate the spread of COVID-19 and contain the pandemic (or justified by such goals) fall well short of core CRC principles regarding non-discrimination; adhering to the child's best interests; safeguarding the right to life, survival and development; and respecting children's views. Regarding the latter, the US Office of Refugee Resettlement has reportedly blocked minors from speaking to advocates or the media (O'Toole and Carcamo, 2020). Importantly, the US government is currently separating families at the US-Mexico border, sometimes placing children in holding centers temporarily, and then summarily deporting them in contravention of human rights standards for the protection of minors. "Hundreds of migrant children and teenagers have been swiftly deported by American authorities amid the coronavirus pandemic without the opportunity to speak to a social worker or plea for asylum from the violence in their home countries - a reversal of years of established practice for dealing with young foreigners who arrive in the United States" (Dickerson, 2020). 


\section{Seeking Just Migration Policies: COVID-19 and Beyond}

UN Secretary General António Guterres recently stressed the global community's obligation to support refugees and asylum seekers during the pandemic. "We all have a vested interest to ensure that the responsibility of protecting the world's refugees is equitably shared," he noted, "and that human mobility remains safe, inclusive, and respects international human rights and refugee law" (UN News, 2020c). Social work scholars and practitioners must join in efforts to build solidarity with forced migrants during a time of heightened vulnerability for this population. Indeed, Jacqueline Bhabha (2018) has challenged immigrant rights activists and community members to go beyond "impressive outpourings of popular support" through neighborly assistance and to marshal "determined and skillful political leadership to outmaneuver the xenophobic hatred in evidence today" (116). The mass mobilization of support for overturning historic racial injustices in the United States and other parts of the world through the Black Lives Matter movement could mark a new beginning for tackling racism and xenophobia in all its forms, especially as directed against those crossing national borders (Libal \& Kashwan, 2020).

Given rising anti-immigrant sentiment in many countries of the Global North, advocacy for asylum seekers and refugees must entail more purposeful and creative approaches at local, national, and global levels (Garcini et al., 2020). Here, international collaboration among activists can help facilitate trans-national solidarity and help overcome the isolation of such work conducted within individual countries. As shown, during COVID-19 the rights of forced migrants living in camps, those languishing in detention, and refugees permanently resettled in a third country are being systematically violated throughout the world. A number of steps can be taken to address their plight, but these will demand sustained organizing and concerted advocacy. For example, we can press for releasing detained migrants in the USA, including unaccompanied children, and support employing community-based alternatives while asylum seekers await adjudication of their cases. The denial of the right to claim asylum at the US-Mexico border, and similar processes in other parts of the world, should also be a priority.

These circumstances also underscore the need for greater public education to support the rights of all migrants, especially those with heightened vulnerabilities, such as unaccompanied children (Monico et al., 2019; Berthold \& Libal, 2016). Social work scholars can engage in research that focuses on the impact of current immigration provisions on child development, while documenting the significant harm caused by restrictive "pandemic-justified" policies on the lives of refugees and asylum-seekers. Disseminating findings is critical to ensuring rights-affirming policies for forced migrants and other immigrants. Given the timeliness of these issues, sharing this work immediately and making it accessible is imperative. Thus, writing op-eds, policy briefs, and for publication on blogs/websites, etc., to reach a broader audience will help insure a wider impact of such work. In addition, acting on this research is critical, and thus the need to use professional associations and other means to lobby/advocate on these issues. Given global social protest, and the outcome of the national elections in the USA, the opportunity exists to address immediate and long-terms policies to support the rights of all migrants, regardless of immigration status.

As we noted earlier in this article, the 14 Principles for Protection developed by leading refugee and immigrant scholars and activists provides a platform for attending to the human rights of refugees, asylum seekers and other migrants during global public health emergencies, such as COVID-19. These guidelines distill international human rights law, highlighting the particular human rights at stake during our current global pandemic. These principles, now signed by more than 1000 experts in the field, represent collective action to realize and enforce the rights of refugees, asylum seekers, and other migrants. Alicia Ely Yamin (2020) recently asserted that collective action for health rights and social justice will be essential following the pandemic: "What the world and our health care systems and societies look like after this phase of the pandemic depends on how we collectively think, and in turn what we do to demand our governments and other powerful actors to act differently. We must shrink the curve, and create pressure for equity." Applying this mandate to address the human rights of those fleeing conflict, persecution, and other material conditions that endanger their lives is one of the key challenges of our era.

\section{References}

Alemi, Q., Stempel, C., Siddiq, H., \& Kim, E. (2020). Refugees and COVID-19: Achieving a comprehensive public health response. Bulletin of the World Health Organization, 98, 510-510A.

American Civil Liberties Union. (2020). Groups file challenge to Trump administration's illegal border exclusion. https://www.aclu.org/pressreleases/groups-file-challenge-trump-administrations-illegal-borderexpulsions

Amnesty International. (2020a). USA: Update to Amnesty International Report on COVID-19 in US immigration detention (31 August 2020). https://www.amnesty.org/en/documents/amr51/ 2958/2020/en/

Amnesty International. (2020b). USA: "We are adrift, about to sink." The looming COVID-19 disaster in United States immigration 
detention facilities. https://www.amnesty.org/download/ Documents/AMR5120952020ENGLISH.PDF

Amon, J. J. (2020). COVID-19 and detention: Respecting human rights. Health and Human Rights Journal. https://www.hhrjournal .org/2020/03/covid-19-and-detention-respecting-human-rights/

Averbuch, M. (2020). With coronavirus spreading, Mexico vowed to empty detention centers - but migrants were thrust into chaos and danger. https://theintercept.com/2020/05/11/coronavirusmigrants-mexico/

Balcioglu, Z., \& Erdogan, M. (2020). What does it mean to be an urban refugee in Turkey during a pandemic? https://www.opendemocracy. net/en/north-africa-west-asia/what-does-it-mean-be-urbanrefugee-turkey-during-pandemic/

Berthold, S. M., \& Libal, K. R. (2016). Migrant children's rights to health and rehabilitation: A primer for US social workers. Journal of Human Rights and Social Work, 1(2), 1-11

Berthold, S. M., \& Libal, K. R. (Eds.) (2019). Refugees and asylum seekers: Interdisciplinary and comparative perspectives. Praeger.

Berwick, D. M., Gale, L., Barksdale, F., Hauptman, M., et al. (2020). Protecting Incarcerated People In The Face of COVID-19: A Health and Human Rights Perspective. Health Affairs Blog. https:// doi.org/10.1377/hblog20200428.846534/full/

Bhaba, J. (2018). Can we solve the migration crisis? Medford, MA: Polity Press.

Biden Harris (n.d.). The Biden plan for securing our values as a nation of immigrants. https://joebiden.com/immigration/

Boffey, D. (2020). Clashes as thousands gather at Turkish border to enter Greece. The Guardian. https://www.theguardian.com/world/2020/ mar/01/thousands-gather-at-turkish-border-to-cross-into-greece

Carassava, A. (2020). Greece extends lockdown on more than 120,000 migrants, refugees. Voice of American News. https://www. voanews.com/covid-19-pandemic/greece-extends-lockdownmore-120000-migrants-refugees

Cecco, L. (2019) Canada took in more refugees than any other country in 2018 UN says The Guardian. https://www.theguardian.com/ world/2019/jun/19/canada-refugees-resettlement-un-report2018\#: :text=Canada\%20resettled\%2028\%2C100\%20refugees\% 20in,refugees\%20(UNHCR)\%20on\%20Wednesday

Centers for Disease Control and Prevention (CDC). (n.d.). COVID19 in newly resettled refugee populations. https://www.cdc. gov/coronavirus/2019-ncov/need-extra-precautions/refugeepopulations.html

CDC. (2020a). COVID-19 in Correctional and Detention Facilities United States, February-April 2020. Morbidity and Mortality Weekly Report (MMWR). https://www.cdc.gov/mmwr/volumes/ 69/wr/mm6919e1.htm

CDC. (2020b). Interim final rule: Control of communicable diseasesforeign quarantine; suspension of introduction of persons into the United States from designated foreign countries or places for public health purposes. https://www.cdc.gov/quarantine/ordersuspending-introduction-certain-persons.html

CDC. (2020c). Interim guidance on management of coronavirus disease 2019 (COVID-19) in correctional and detention facilities. https://www.cdc.gov/coronavirus/2019-ncov/community/ correction-detention/guidance-correctional-detention.html

Cheatham, A. (2020). U.S. detention of child migrants. Council on Foreign Relations. https://www.cfr.org/backgrounder/usdetention-child-migrants

Clarke, S. et al., (2020). Potential impact of COVID-19 on recently resettled refugee populations in the United States and Canada: Perspectives of refugee healthcare providers. Journal of Immigrant and Minority Health. E-Pub ahead of print. https:// doi.org/10.1007/s10903-020-01104-4

Columbia University's Mailman School of Public Health, Cornell Law School, and The New School's Zolberg Institute on Migration and Mobility. (2020). Human mobility and human rights in the
COVID-19 pandemic: Principles of protection for migrants, refugees, and other displaced persons. https://www.publichealth. columbia.edu/public-health-now/news/principles-protectiondisplaced-persons-during-pandemic

Cordaid. (2020). COVID-19 in refugee camps: "Europe is shooting itself in the foot." https://www.cordaid.org/en/news/covid19-in-refugee-camps-europe-is-shooting-itself-in-the-foot/

Coronado, A. (2020). Migrants and advocates call to close detention centers as COVID-19 spreads. Texas Observer. https://www. texasobserver.org/migrants-and-advocates-call-to-closedetention-centers-as-covid-19-spreads/

Cosse, E. (2020). Greece again extends Covid-19 lockdown at refugee camps authorities should end discriminatory restrictions. Human Rights Watch. https://www.hrw.org/news/2020/06/12/greeceagain-extends-covid-19-lockdown-refugee-camps

Da Silva, C. (2020). Doctors launch 24-hour nationwide protest calling for release of immigration detainees amid coronavirus pandemic. Newsweek. https://www.newsweek.com/doctors-launch-callrelease-all-ice-detainees-covid-coronavirus- 1503780

Dickerson, C. (2020). 10 years old, tearful and confused after sudden deportation. New York Times. https://www.nytimes. com/2020/05/20/us/coronavirus-migrant-childrenunaccompanied-minors.html

Echavarri, F., \& Lanard, N. (2020). ICE Asked parents to choose between family separation and prolonged detention-during a pandemic. Mother Jones. https://www.motherjones.com/politics/ 2020/05/ice-family-separation-detention-flores-settlementcoronavirus/

Estrada-Tanck, D. (2016). Human security and human rights under international law: The protections offered to persons confronting structural vulnerability. Hart Publishing

European Council on Refugees and Exiles. (2020). Greece: Authorities block scrutiny of camp conditions, lead poisoning adds to risks in Moria 2.0, concern over remote interviews. https://www.ecre. org/greece-authorities-block-scrutiny-of-camp-conditions-leadpoisoning-adds-to-risks-in-moria-2-0-concern-over-remoteinterviews/

Erfani, P., Uppal, N., Lee, C. H., Mishori, R., \& Peeler, K. R. (2020). COVID-19 testing and cases in immigration detention centers, April-August 2020. JAMA. https://doi.org/10.1001/ jama.2020.21473

Fallon, K. (2020). Greece: 148 refugees test positive for COVID19, all asymptomatic. Aljazeera. https://www.aljazeera.com/ news/2020/04/greece-148-refugees-test-positive-covid-19asymptomatic-200421134039733.html

Fouskas, V., Gökay, B., \& Vankovska, B. (2020). Special issue: Crisis in the Eastern Mediterranean and COVID-19. Journal of Balkan and Near Eastern Studies, 22(3), 295-305.

Garcia Bochenek, M. (2020). Trump administration uses pandemic as an excuse to expel migrants: Summary expulsion power expanded indefinitely. Human Rights Watch. https://www.hrw. org/news/2020/05/20/trump-administration-uses-pandemicexcuse-expel-migrants

Garcini, L. M., Mercado, A. Domenech Rodríguez, M. M. \& Paris, M. (2020). A tale of two crises: The compounded effect of COVID19 and anti-immigration policy in the United States. Psychological Trauma: Theory, Research, Practice, and Policy, 12(S1), S230-S232.

Gelatt, J., Batalova, J., \& Capp, R. (2020). An early readout on the economic effects of the COVID-19 crisis: Immigrant women have the highest unemployment. Migration Policy Institute Factsheet. https://www.migrationpolicy.org/sites/default/files/ publications/COVID-19-Unemployment-Women-FS-FINAL.pdf

Girls Not Brides. (2020). COVID-19, and child, early, and forced marriage: An agenda for action. https://www.girlsnotbrides.org/ resource-centre/covid-19-and-child-early-and-forced-marriagean-agenda-for-action/ 
Gonzalez, D. (2020). Protesters call for ICE to release detainees because of coronavirus. USA Today. https://www.usatoday.com/story /news/nation/2020/04/11/coronavirus-protesters-call-releaseimmigration-detainees/2978010001/

Harding, S., \& Libal, K. (2020). Doing something to fight injustice: Voluntarism, private and community co-sponsorship, and refugee resettlement as political engagement in the United States. In S. Labman \& G. Cameron (Eds.), Private refugee sponsorship: Concepts, cases and consequences, pp. 247-263. McGill-Queen's University Press.

Hathaway, J.C. (2005). The Rights of Refugees under International Law. Cambridge University Press.

Hauslohner, A. (2020). Biden wants more refugees, but it could take years to rebuild the resettlement system. The Washington Post. https://www.washingtonpost.com/politics/2020/12/02/bidenrefugees-resettlement-trump/

Helling v. McKinney, (1993). 509 U.S. 25, 33

Hsu, S. S. (2020a). U.S. judge: ICE must disclose efforts to protect parents, not just children, held at family detention centers. https://www.washingtonpost.com/local/legal-issues/us-judgeice-must-justify-detentions-of-parents-held-more-than-20days-at-family-detention-centers/2020/04/27/d2ecccbc-88b511ea-9dfd-990f9dcc71fc_story.html

Hsu, S. S. (2020b). U.S. judge widens order, urging ICE to release migrant families with young children in coronavirus outbreak. Washington Post. https://www.washingtonpost. com/local/legal-issues/us-judge-widens-order-urging-icerelease-of-migrant-families-with-young-children-incoronavirus-outbreak/2020/03/30/8226ed06-7296-11ea85cb-8670579b863d_story.html

Human Rights Watch (1998). Detained and deprived of rights: Children in the custody of the US Immigration and Naturalization System. HRW Legacy Reports, 10(4). https:// www.hrw.org/legacy/reports98/ins2/berks98d-01.htm

Human Rights Watch. (2020a). Detained children left out of Covid19 response: Step up releases from jails, prisons. https://www. hrw.org/news/2020/05/14/detained-children-left-out-covid19-response

Human Rights Watch. (2020b). Greece: Island camps not prepared for COVID. https://www.hrw.org/news/2020/04/22/greece-islandcamps-not-prepared-covid-19\#

Human Rights Watch. (2020c). Greece: Nearly 2,000 new arrivals detained in overcrowded, mainland camps. https://www. hrw.org/news/2020/03/31/greece-nearly-2000-new-arrivalsdetained-overcrowded-mainland-camps

Human Rights Watch. (2020d). Mexico: Free detained migrants amid pandemic. allegations of excessive force to quell protests. https:// www.hrw.org/news/2020/04/15/mexico-free-detainedmigrants-amid-pandemic\#

Human Rights Watch. (2020e). US: Covid-19 policies risk asylum seekers' lives. Rejections at borders increase health concerns. https://www.hrw.org/news/2020/04/02/us-covid-19-policies-riskasylum-seekers-lives

Inter-Agency Standing Committee secretariat (2020). Interim guidance COVID-19: Focus on persons deprived of their liberty. https:// interagencystandingcommittee.org/system/files/2020-03/ IASC $\% 20$ Interim\%20Guidance \%20on\%20COVID-19\%20-\% 20Focus\%20on\%20Persons\%20Deprived\%20of\%20Their\% 20Liberty.pdf

International Rescue Committee. (2020). New IRC analysis reveals risk that coronavirus transmission rates in Moria, $\mathrm{Al} \mathrm{Hol} \mathrm{and} \mathrm{Cox's}$ Bazar refugee camps could outpace those seen on the Diamond Princess cruise ship. https://www.rescue.org/press-release/ new-irc-analysis-reveals-risk-coronavirus-transmission-ratesmoria-al-hol-and-coxs
Jordan, M. (2020). U.S. must release children from US detention centers, judge rules. New York Times. https://www.nytimes.com/2020/06/26/ us/immigrant-children-detention-centers.html

Karagkounis, V. (2017). Social work in Greece in the time of austerity: Challenges and prospects. European Journal of Social Work, 20(5), 651-665.

Libal, K., \& Kashwan, P. (2020). Solidarity in times of crisis. Journal of Human Rights, 19(5), 537-546.

Margolis, H. (2020). Greece migrant camps unfit for pregnant people. Human Rights Watch. https://www.hrw.org/news/2020/05/27/ greece-migrant-camps-unfit-pregnant-people

Médecins Sans Frontières (MSF) (2020). MSF calls on Mexico to prevent spread of COVID-19 and release migrants from detention centers. https://reliefweb.int/report/mexico/msf-calls-mexicoprevent-spread-covid-19-and-release-migrants-detention-centers

Merchant, N. (2020). Judge demands ICE better explain why it won't release kids. Washington Post. https:// www.washington post.com/health/judge-demands-icebette r-explain-why-it-wont-relea se-kids/2020/05/22/ f0104038-9c94-11ea-ad79-eef7cd734641_story. html

Monico, C., Rotabi, K., Vissing, Y., \& Lee, J. (2019). Forced childfamily separations in the Southwestern US border under the "zero tolerance" policy: The adverse impact on well-being of migrant children (part 2). Journal of Human Rights and Social Work, 4, 180-191.

Montoya-Galvez, C. (2020). Second immigrant dies of coronavirus complications while in ICE custody. CBS News. https://www. cbsnews.com/news/second-immigrant-dies-of-coronaviruscomplications-while-in-ice-custody/

Mpoke Bigg. (2020). Vulnerable asylum-seekers struggle to access medical care on overcrowded Greek islands. https://www. unhcr.org/en-us/news/stories/2020/2/5e4fc07b4/vulnerableasylum-seekers-struggleaccess-medical-care-overcrowdedgreek. html\#: :text=With\%20more\%20than\%2018\%2C000\%20people, conditions $\% 20$ at $\% 20$ Moria\%20reception $\% 20$ centre

Narea, N. (2020). Trump is continuing deportations during the pandemic. It's causing the coronavirus to spread. Vox. https://www.vox. com/2020/5/12/21250540/coronavirus-immigration-limits-trumpdeportations-guatemala-honduras

Nicolosi, S. (2020). Non-refoulement during a health emecy. EJIL: Talk!. Blog of European Journal of International Law. https:// www.ejiltalk.org/non-refoulement-during-a-health-emergency/

Orcutt, M., et al. (2020). Correspondence: Global call to action for inclusion of migrants and refugees in the COVID-19 response. Lancet Migration, 395, 1482.

O'Toole, M., \& Carcamo, C. (2020). Citing coronavirus, Trump officials refuse to release migrant children to sponsors, and deport them instead. LA Times. https://www.latimes.com/politics/ story/2020-05-12/trump-officials-coronavirus-refuse-releasingmigrant-kids

Papoutsi, E. (2020). The protection of unaccompanied migrant minors under international human rights law: Revisiting old concepts and confronting new challenges in modern migrant flows. American University International Law Review, 35(2), 219-258.

Popescu, M., \& Libal, K. R. (2018). Introduction: Social work practice with immigrants and refugees in an era of rising anti-immigrant sentiments. Advances in Social Work, 18(3), i-x.

Preston, J. (2020). Biden will try to unmake Trump's immigration agenda. It won't be easy. The Marshall Project. https://www. themarshallproject.org/2020/11/23/biden-will-try-to-unmaketrump-s-immigration-agenda-it-won-t-be-easy?utm_medium= email\&utm_campaign=share-tools\&utm_source=email\&utm content $=$ post-top 
Ramji-Nogales, J., \& Goldner Lang, I. (2020). Freedom of movement, migration, borders. Journal of Human Rights, 19(5), 593-602.

Refugees International. (2020). Advocacy letter: Indefinite suspension of protections for asylum seekers and unaccompanied children, under May 19, 2020 order by the Center for Disease Control and Prevention. https://www.refugeesinternational.org/reports/ 2020/5/27/indefinite-suspension-of-protections-for-asylum-seekersand-unaccompanied-children-under-may-19-2020-order-by-thecenters-for-disease-control-and-prevention

Roldan, C. (n.d.). Refugee resettlement agencies are providing essential services during COVID-19. Fiscal Policy Institute. http:// fiscalpolicy.org/refugee-resettlement-agencies-are-providingessential-services-during-covid-19

Slack, J., \& Heyman, J. (2020). Asylum and mass detention at the U.S.Mexico border during Covid-19. Journal of Latin American Geography, 19(3), 334-339.

Somin, I. (2020). The danger of America's coronavirus immigration bans. The Atlantic. https://www.theatlantic.com/ideas/archive/ 2020/06/danger-americas-coron avirus-immig rationbans/613537/

Sun, N. (2020). Applying Siracusa: A call for a general comment on public health emergencies. Health and Human Rights Journal. E-publication. https://www.hhrjournal.org/2020/04/applyingsiracusa-a-call-for-a-general-comment-on-public-healthemergencies/

Tolan, C. (2020). Hand sanitizer is still considered contraband in some prisons around the country. CNN. https://www.cnn. com/2020/05/05/us/coronavirus-prison-hand-sanitizer-contrabandinvs/index.html

Unite Oregon. (n.d.). Coronvirus immigrant and refugee support fund. https://www.uniteoregon.org/covid19_support_fund

United Nations. (1966a). International Covenant on Civil and Political Rights. https://www.ohchr.org/en/professionalinterest/pages/ccpr. aspx

United Nations. (1966b). International Covenant on Economic, Social and Cultural Rights. https://www.ohchr.org/en/ professionalinterest/pages/cescr.aspx

United Nations. (1984). Convention Against Torture and Other Cruel, Inhuman, or Degrading Treatment or Punishment. https://www. ohchr.org/en/professionalinterest/pages/cat.aspx

United Nations. (1989). Convention on the Rights of the Child. https:// www.ohchr.org/en/professionalinterest/pages/crc.aspx

United Nations. (2002). Optional Protocol to the Convention on the Rights of the Child on the Sale of Children, Child Prostitution and Child Pornography. https://www.ohchr.org/EN/ ProfessionalInterest/Pages/OPSCCRC.aspx

UN Committee on the Protection of the Rights of All Migrant Workers and Their Families and Committee on the Rights of the Child. (2017a). Joint general comment No. 3 (2017) of the Committee on the Protection of the Rights of All Migrant Workers and Members of Their Families and No. 22 (2017) of the Committee on the Rights of the Child on the general principles regarding the human rights of children in the context of international migration. https:// documents-dds-ny.un.org/doc/UNDOC/GEN/G17/343/59/PDF/ G1734359.pdf?OpenElement

UN Committee on the Protection of the Rights of All Migrant Workers and Their Families and Committee on the Rights of the Child. (2017b). Joint general comment No. 4 (2017) of the Committee on the Protection of the Rights of All Migrant Workers and Members of Their Families and No. 23 (2017) of the Committee on the Rights of the Child on the general principles regarding the human rights of children in the context of international migration in countries of origin, transit, destination and return. https:// documents-dds-ny.un.org/doc/UNDOC/GEN/G17/343/65/PDF/ G1734365.pdf?OpenElement
UN High Commissioner for Refugees (UNCHR). (n.d.) Refugee camps. https://www.unrefugees.org/refugee-facts/camps/

UNHCR. (2003). Framework for durable solutions for refugees and persons of concern. https://www.refworld.org/docid/4124b6a04. html

UNHCR. (1997). Guidelines in policies and procedures in dealing with unaccompanied children seeking asylum. https://www.unhcr. org/3d4f91cf4.pdf

UNHCR. (2017). Global Trends: Forced displacement in 2017. https:// www.unhcr.org/globaltrends2017/\#: :text $=85 \% 25 \&$ text $=$ Developing \%20regions\%20hosted $\% 2085 \% 20$ per,total\% 20(6.7\%20million\%20refugees)

UNHCR. (2020a). As COVID-19 pandemic continues, forcibly displaced children need more support than ever. Joint statement by Henrietta Fore, UNICEF Executive director, and Filippo Grandi, UN High Commissioner for Refugees. https://www.unhcr. org/en-us/news/press/2020/4/5e9d4c044/covid-19-pandemiccontinues-forcibly-displaced-children-need-support.html

UNHCR (2020b). Beware long-term damage to human rights and refugee rights from the coronavirus pandemic: UNHCR. https:// www.unhcr.org/en-us/news/press/2020/4/5ea035ba4/bewarelong-term-damage-human-rights-refugee-rights-coronaviruspandemic.html

UNHCR. (2020c). Greece: Update on COVID-19 response and other acute needs. https://data2.unhcr.org/en/documents/details/75314

UNHCR. (2020d) West and Central Africa: UNHCR steps up efforts as combined challenges of conflict and coronavirus threaten millions of people. https://www.unhcr.org/en-us/news/briefing/ 2020/4/5e995 d934/west-central-africa-unhcr-steps-effor tscombined-challenges-conflict-coronavirus.html

United Nations High Commissioner for Refugees USA. (n.d.) Resettlement. https://www.unhcr.org/en-us/resettlement.html\#: :text=Resettlement\% 20States $\% 20$ provide $\% 20$ the $\% 20$ refugee,for $\% 20$ consideration $\%$ 20by\%20resettlement\%20countries

UN Network on Migration (n.d.). COVID-19 and immigration detention: What can governments and other stakeholders do? https:// migrationnetwork.un.org/sites/default/files/docs/un_network_ on_migration_wg_atd_policy_brief_covid-19_and_immigration_ detention_0.pdf

UN News. (2020a). COVID-19 crisis putting human trafficking victims at risk of further exploitation, experts warn. https://news.un.org/ en/story/2020/05/1063342

UN News. (2020b). COVID-19 pandemic quickly becomes a 'childrights crisis': Daily death rates could spike by 6,000 for underfives. https://news.un.org/en/story/2020/05/1063822

UN News. (2020c). UN chief underlines need to protect refugees and migrants in COVID-19 pandemic. https://news.un.org/en/story/ 2020/06/1065322

UN Office of the High Commissioner for Human Rights (OHCHR). (2020). US: Migrants "held for processing" should be released from COVID-19 high-risk detention centres. https://www.ohchr. org/EN/NewsEvents/Pages/DisplayNews.aspx?NewsID=25827\& LangID $=\mathrm{E}$

US Committee on Refugees and Immigrants. (2020). USCRI advocates to protect unaccompanied children at our border. https://reliefweb. int/report/united-states-america/uscri-advocates-protectunaccompanied-children-our-border

Villagran, L. (2020, June 10). The Trump administration is turning away unaccompanied children at the border because of coronavirus. USA Today. https://www.usatoday.com/story/news/ nation/2020/06/10/border-patrol-rejects-migrant-children-cdcrule-amid-covid-19/5333392002/

WHO. (2020). Protecting yourself and others from the spread COVID-19. https://www.who.int/emergencies/diseases/novel-coronavirus2019/advice-for-public 
World Health Organization (WHO). (n.d.). Naming the coronavirus disease (COVID-19) and the virus that causes it. https://www. who.int/emergencies/diseases/novel-coronavirus-2019/technicalguidance/naming-the-coronavirus-disease-(covid-2019)-and-thevirus-that-causes-it
Yamin, A. E. (2020). Post-pandemic collective action for health rights and social justice is essential. OpenGlobalRights. https://www. openglobalrights.org/after-the-pandemic-what/ 